\title{
An Approach to the Teaching of Architectural History
}

\author{
KAREL A. BAKKER \\ University of Pretoria \\ Republic of South Africa
}

\section{INTRODUCTION}

The questions posed by this paper are whether a different approach to the teaching of Architectural History might assist an evolving process of cultural co-construction which transcends the confines of ideologies posed by power ecologies, and whether there is need for a peculiar, contextspecific approach to teaching Architectural History in South Africa (A society currently involved in an evolutionary process of social Reconstruction and Development)?

These questions are imperative because the South African Architectural fraternity is in the fortunate position to be trusted with the task of reformulating present syllabi without prescription or interference. However it is widely agreed that this task has as formative context an endeavour to evolve out of a biased education system towards a position of relevancy.

Before inquiring into aspects which might inform the construction of an approach, it might be helpful to ask if archaeological knowledge of historical spatial habitat might be of help per se:

- In normalising societal inequalities relating to access to particular historical knowledge of cultural historical process and heritage

- In the communal transcendence of the destructive racial dualities of the past (for instance the dialectics coloniser:colonised, and White European : Black African) which remain within our education system as well as the evolving spatial geography,

- In defining our individual as well as collective identity spatially and architecturally whilst there is a far from resolved search for multicultural identity within the country itself, together with the misperception that culture means group and in particular ethnic/racial group, and

- In expressing that identity whilst finding itself on the cultural fringes in Africa, the Old World as well as newly emerged, maturing and assertive cultural conglomerates in the New World?

\section{DEFINING A ROLE FOR ARCHITECTURAL HISTORY IN SOCIETY}

If one accepts that education in Architectural History should

be involved in addressing such issues, it may be of help to define what purpose or purposes architecture and history generally, and architectural history specifically, may serve vis a vis society:

- Architecture may be a discipline which strives, together with other disciplines and society as a whole, to coconstruct a sustaining and enduring environment for real people within a real world in which the legitimate yearnings of society, and those rituals underpinning meaningful life, may find full expression as defined within cultural or sub-cultural frameworks. The question is usually whether architects are subservient to, and help sustain controlling power-knowledge systems, or wether they are able to transcend the restrictions of the ideologies of power ecologies in order to serve real needs of humanity.

- History could have a positive force in human affairs, primarily as a form of cognition and mode of self-identity, and by providing a way of orientating human beings in time by means of historical consciousness. In the same token access to the contents of historical process and specific historical knowledge may be seen as an empowering tool in the liberation from confining systems of power-knowledge.

- Architectural history may inter alia be seen as being a repository of mankind's solutions to the manifold problems of settlement, space-making and building for the purposes of dwelling and giving spatial and architectural expression to cultural values and beliefs. It may furthermore expose the relationship (positive and negative) between the built environment, the process of design and making towns and buildings, and the abstract and concrete contexts within which architecture emerges. As a whole the acknowledgement of tradition holds the potential to enrich future endeavours towards cultural rootedness by means of the process of feedback.

In terms of the above definitions it would seem clear that education in architectural history can make a contribution, albeit of limited scope, if we take a broader view of

- our definition of history

- our definition of culture and society, 
- our view of the nature of educationists' linkage with society and

- the extent in which context determines the approach to and the content of the architectural educational process.

\section{CONSTRUCTING AN APPROACH}

The following aspects are deemed relevant in the formulation of an approach to a course in architectural history which would answer the tentatively stated context-bound societal needs:

\subsection{The evolving Ecosystemic episteme}

If one accepts that the Modernizing rationalism of the 20th Century was the swansong of the Cartesian/Newtonian paradigm, it might be useful to look at how the epistemology of the evolving Ecosystemic paradigm (Bateson (1972; 1985), Laszlo (1973), Prigogine (1979) and Prigogine et al (1985 [1984])) may inform our subject. Within the said epistemology the study of history of architecture should rather be a study of the history of environments, both abstract and physical, together with the interrelationships between environments. This involves acknowledging the environment around architectural systems, exposing the recursive relationships between systems occurring within environments, and identifying structural linkages between systems. Obviously the construction of an historical text would imply many subsystems, systems and suprasystems, and many relationships. Certain systems and relationships might be more significant and/or more functionally useful than others, regarding on the subjective viewpoint of the observer.

However, the search for probable relationships implies the availability of a wide base of historical data founded on rigorous research, as well as experience, creativity and interpretative skills on the part of the subject. Furthermore, it would imply a more complex description of the contents and relationships between contexts of historical architectural inquiry than is presently the case, as well as real exposure of the complex process of design translation from context system to product system.

\subsection{An ecosystemic view of society and culture}

Within the mindset of modernising rationalism society is seen as an object, and culture a collection of intellectual traits, refinements, tastes and manners common to a group, like for instance a racial, ethnic or national group. How would Ecosystemic description of society and culture inform our inquiry?

- Society is the "total network of relations between human beings' and culture as 'communalities defined by societal, non-genetically bound process.' (Toynbee, 1988, p.43).

- Culture does not exist as a concrete reality of its own but exists as abstraction in the mind of the investigator which, rather than seeing culture as being a packaged construct, may perceive it as regularities of interactions and meanings within a dialectic of social systems and society. This totality can be described as a symbolic meaning system, ie as systems of ideas or meanings maintained by social groups within society through time (Rohner, 1984, p. $111 ; 120)$. Material artifacts are included in the contents of a symbolic meaning system (Jahoda, 1984).

Lessons implied for architectural history would be

- that culture is not a synonym for 'group', but rather a living, learning ecological system within which architecture is a subsystem

- that a symbolic meaning system may be decoded through interpretation of perceived dialectical constructionist and revisionist processes

- that architecture also exists as subsystem of societal symbolic meaning systems.

\subsection{Evolving trends in Metahistory and historiography}

Post-modern historicists identify a cultural crisis of orientation resulting from the paradigm of Modernising rationalism. This crisis is likewise experienced in African society. According to Rsen, (1993, p.207-10) the Post-modern critique on modern historical thought has at its core

- the rejection of the theoretical approach to historical experience (as reflected in the hardcore analytical methods of structural history). It is in other words antitheoretical, and a rejection of the Modernising rationalism of historical thought in favour of a softer, hermeneutic approach complementing analytical method .

- a tendency towards viewing history as artefact rather than scientific procedure.

- a tendency to eschew comprehensive, universalist history in favour of a dialectic of macro- and micro-history and with an emphasis on narrative qualities.

- a rejection of the conceptual strategy of constructing explicit frameworks of historical interpretation, eg in the mould of Marxist theory or Western Modernization theory, in favour of a theory of internal subjectivity in which the subject of concern is a central illuminating part of historical experience, and the focus is on discovering and presenting patterns of significance inherent to that subject by means of micro-history, and

- the acceptance of subjective reason as a generative quality in both research procedure and theory.

The obvious question would be if such a [Western] view of history would be compatible with evolving trends in societies proclaiming to want to evolve indigenous knowledge systems and stand outside the prevailing Western episteme, eg most societies in Africa? With specific reference to post-colonial African society, readings of Senghor (1965), Mbiti (1961), Irele (in Hountondji (1983 [1976])), Gebhard (1991, p.204-5), Durand (in Wickert, 1967, p.255), Abraham (1967 [1962, p.115), Mazrui (in Mowoe et al (1986)), Davidson (1991, p.7) and others indicate unity and continuity of cultural growth, an African cultural koine, a paradigm of African society, resulting mostly from millenia 
of indigenous experience, but also partly from Eurocentric colonialist description of observed society (Pieterse, 1992)). Within that paradigm, a holistic concept of man, origin, and being exists, within which paradigm history is viewed from an anti-theoretical and anti-universalist base, where all historical evidence (both material and non-material) is accepted in an additive and syncretist manner with full cognisance of contextual relatedness, and with dense microand macrohistorical narrative, together with societal material- and other non-material action, as product of history. However, that last mentioned paradigm is also regarded by many in Africa as an anthropologising view of African being (Hountondji, 1983)), and rejected by most philosophers claiming a unique Africaness but simultaneously employing Western knowledge systems in construing current meaning systems (Mudimbe, 1988).

However, the supposition is made that an Ecosystemic view of history, as also reflected within current trends in Metahistory, could provide a relevant metaframework within which the complexities and wide range of African historiographical endeavour may yet find full expression (be it within the revisionist framework inspired by Ngritude, the anti-anthropologising, pragmatist stance within current African reactionary philosophy, within hybrid frameworks of African Islamic or African Christian expression, or whatever), and within which metaframework the complexities and interrelatedness of diverse historical process and meaning may be made explicit without fear of any framework being pigeonholed as would be the case within a universalist view, must be tested to the will of society.

To relate this to the topic of architectural history, it would indicate

- discourse about diverse interpretations of existential meaning reflected in the built/inhabited environment

- the need for looking beyond existing internationalist or nationalist power ecologies's definitions of cultural expression and seeing smaller context-bound architectural systems as structurally connected with a bigger whole that co-exists with other cultural systems of world society

- that architectural history could strive to come closer to constructing and revealing a more complete historical reality by eschewing ideologically bound structural frameworks, by including all historical actors involved and by constructing 'thicker/denser' descriptions

- the possibility that architectural history, seen as artefactual residue of a decoding process, may be employed in the process of continuously revitalising historical artefactual material that they be meaningful within disparate and evolving contexts.

\subsection{Ecosystemic thought and theory of architectural history}

From Vitruvius up to the Modern, theory of architectural history for the most part been leaning strongly towards existing as etiological base for the architecture of the ruling elite within a specific cultural paradigm (Onians, 1988, p.4), whilst cauterising 'untypical', 'dangerous' or 'revolutionary' architecture and/or theories. This leaning coincides with tendencies within structural history. Within post-modern architectural thought all historical architectural systems exist as design quarry (Portoghesi, 1981; Kostof, 1985), and may be employed within a meaning framework (eg bricolage (Rowe, 1987, p.185-90)).

Within the Ecosystemic paradigm however,

- these systems can only be understood within their contexts, and the resultant understanding is influenced by the interactive relationship between the ecology of interpreter and the ecology of the systems

- the process of decoding historical architectural artifacts involves the artifacts and the abstract world of the historian in a interactive process by which historical knowledge is left as new artefactual residue within the cultural pool of knowledge (Fisher, 1992, p.10-4)

- all levels of historical interpretation, being the pre-iconographic, iconographic and iconological (Panofsky, 1955, p.41-2), are accessible from the direction of both historical context and the interpretative context. It is clear that any ideology informing the mode of interpretation is totally transparent. It is also clear that within Ecosystemic epistemology there is no search for proof or absolute truths, only more probable, richer ('thicker/denser') and more complex descriptions.

If we think back on the discussion of trends in metahistory, an Ecosystemic approach to architectural historiography would make it possible to get closer to historical reality, to let the actors speak from within their historical time frame. This last could be made possible through the action of context reconstruction (Fisher, 1992, p.22), by increasing the scope of knowledge through micro-history, and by constructing 'thicker' descriptions of historical systems. Architectural history may then also be seen as artefact to be employed in the process of cultural autopoiesis.

\subsection{Architecture as a mode of expressing cultural meaning}

According to Fisher architecture, like all artifacts, may be seen as carrier of cultural information or an expression of cultural identity and cultural rootedness. Architecture is produced and exists within specific paradigmatic timeframes, within which the artefact displays in its content and interrelationship of its constituent elements a correspondence with the spirit of the paradigmatically bound cultural system. This whole of specific content and interrelationships may be read as style. A hierarchy of styling exist within culture: style emanating from a way of doing (isochrestic), from mimicking a pre-existing model (skeuomorphic), or from deliberate formalisation. All these manners of styling are informative of cultural content and consciousness. Last cultural information may be regained through historical interpretation and reactivated within a current ecology of ideas (1992, p. 27-8; 34; 38).

It is clear that the architectural historian not only needs 
to be aware of the ecosystem within which architectural artifacts were produced and in which they are to be reconstructed, but must also be aware of his interpretative role within the generative process by which society creates culture through synchronic recursivity and transfers culture through diachronic autopoiesis. This idea of a learning as well as a regenerating societal ecology has far-reaching implications for the teaching of all aspects of architecture, in itself making the teaching of all history imperative. As was seen from the evolving trends in Metahistory, the historian will also be a specialist on local knowledge, a local knowledge from which other knowledge systems might be deconstructed and reconstructed to be contextually relevant.

\subsection{Evolving roles of architectural history}

It is through the history of architecture that the designer may gain access to the understanding of the process of interpretation and transference of cultural meaning, as well as the process of architectural expression of cultural meaning, into built form. This implies an understanding of the process of encoding cultural meaning within the architectural product through the act of architectural design.

However, although the role of tradition and context has become prevalent in the approach to architectural historiography, and apart from snippets of integrated interpretation existing within international and local archaeological, architectural and urban theses, papers and articles no truly ecosystemic interpretation of the corpus of architecture (and where interpretation reaches the iconological level), is common currency as yet. In the light of the above, the theory for an Ecosystemic approach to architectural history proposed by Fisher in 1992 is an important artefact.

In this sense the acceptance of local knowledge, and the founding and nurturing of local architectural histories, which also reflect an Ecosystemic viewpoint, becomes important. Writing and teaching such local histories will require constructing synoptic, generalised frameworks within which both education and research may take place. In this sense it could also be of value to revisit important works that look at architectural historical aspects holistically, those that look at the underlying structure and meaning of artifacts from the fine arts, architecture and cities of historical society, as well as those that view architecture and settlement from a holistic or contextual viewpoint, in the sense that these works could be relevant guides for informing the process of constructing an interpretative framework (It is accepted that we look beyond the paradigmatic bias in terms of the content, in that we look for relevant historiographic theory, method and process). Construction of a framework for filling in the historiography and interpretation of relevant modes of expression of a localised cultural meaning system could then proceed, always being mindful of how the specific context could inform the approach.

\section{THE TEACHING OF ARCHITECTURAL HISTORY}

It would seem as if architectural history teachers may play an extremely important part in exposing the potential role of history in society, the role of history in the formation of culture, the role of history in urban an architectural design, and specifically the process of deliberately encoding spatial systems and related architectural works with current paradigmatically- and contextually bound cultural values. Teachers' role in defining the specific course content and appropriate theory which would eventually equip an architect to be able to interpret the context-bound requirements of any given society, or part of society, then becomes of utmost importance.

Furthermore it seems necessary that those teachers entrusted with the task of teaching architectural history be nurtured and encouraged to develop the skills and knowledge (both broad and specific) required to deal with this complex issue. What could be the make-up of an ideal history teacher? Probably one who is personally involved in the act of historical interpretation and historiography, who is well versed in methodology of historical research, have breadth of context related knowledge and be able to impart the relationship object : context with full cognisance of subjective intent, who is conversant with a wide range of historical architectural and other cultural expressions as well as intimate with specific systems, who understands the complexity of cultural content and process and is immersed in current expressions there-of, who understands the act of architectural design and the theory there-of, and who is sensitive to and perceives emerging patterns of changes in cultural viewpoints and needs.

\section{A RECURSIVE CO-CONSTRUCTIVE RELATION- SHIP BETWEEN SOUTH AFRICAN SOCIETY AND ARCHITECTURAL EDUCATION}

The way in which the idea of race supremacy was developed and applied to its utmost conclusion in South Africa, through the system of Apartheid, inflicted a particular trauma upon South African society, and demanded total expression within all levels of culture in the last fifty years, even in terms of urban spatial order and architectural content. This system not only resulted in large portions of different societies's cultural network systems being severed and rejected, but also in a astounding lack of knowledge about and empathy for the role that architecture and historical environmental knowledge can play in terms of

- gaining an existential foothold within the environment

- in reconstructing shattered cultural identity and

- in orientating societies in space and time.

In terms of the above, there exists a sound reason for establishing a more recursive relationship between society and the architectural education system, and for an Ecosystemically based, Ecosystemically related course in Environmental history which, in terms of its specific aims, 
content and process, could be idiosyncratic in order to specifically achieve

- context specific cultural healing, not only for the traditionally oppressed but also for the recently emancipated oppressors, in order that we might transcend our stifling dialectic relationship (If the previous oppressors are not included in the process there exists a true danger for a process of auto-colonialisation, excluding the possibility of transcendence)

- context specific cultural regeneration which would enable the relevant and appropriate expression of any emerging identity or identities that society and parts of society may formulate, within a context-bound societal symbolic meaning system.

- context specific cultural regeneration that would see an operative understanding of the recursive synchronic and diachronic connection between our symbolic meaning system and that of global society.

However, although a value-free perspective does not exist, although history can only be but subjective, and although there is ample reason to claim for all manners of redress within our society, historians and teachers should eschew [propagandist] histories "rendered turbid and opaque by religious myths, by insufficient philosophical concepts, by party idols" (Croce, 1970, p.283) whilst including them within the broader metaframework of inquiry. Historians and teachers should also be ever mindful of their role in the process of empowering society, in that they might unwittingly find themselves to be operating within a new system of cultural repression. If the focus is on the transcendence of the dialectic of the past, empowerment related to cultural development could, in our specific inquiry, imply making specific historical knowledge accessible for the express purpose of cultural healing, at first maybe with the healing of our most immediate cultural cancer in mind.

I am mindful that the term 'healing' in our present context could be interpreted in many ways depending on the subjective viewpoint, and would require different methods. The recent perspective on the famous African revolutionary Frantz Fanon by Bakker (1993) concludes that, although Fanon $(1973$, p. $252 ; 255)$ preached healing through violence in the face of absolute colonialism because he saw no other possible alternative in his own context, we should heed his call for the possibility of the destruction of the Manichean world inherent in the coloniser: colonised dialectic, through the mutual transcendence of that dialectic within a perspective of a newly created African [continental] value system, especially one that is respectful of the value of European thought but mindful of its shortcomings and negative effects.

Within the stated perspective however, both cultural healing and regeneration are evolving processes which are continuously informed by society as a whole (and of which we are all part), which would imply that we would see our duty to society in its totality rather than to elitist ideology. This change in teaching approach thus actively engages teacher (curator, specialist, inquirer, teacher and prophet), student of architecture (who will be future practitioner, or in other words operative cultural interpreter), and members of society at large (who, for the most part up till now, have suffered from a lack of access to specific knowledge, and who have not been allowed to be part of the process of macrohistoriography, but who are now seen as co-constructers of the societal symbolic meaning system), in a recursive relationship.

\section{CONCLUSION}

I think it would be worthwhile to explore the possibility that a course in Environmental history, which in terms of content takes cognisance of the aspects dealt with in this paper, may equip prospective architects in the arduous but meaningful task of addressing the context bound needs stated in this paper. Only exposure will tell whether South African society will sanction this approach, and whether this approach might find other fertile ground.

To me the question remains whether we as teachers can state, without fear of contradiction, that architects who have gone through our educational system will be equipped to deal with the aspirations toward cultural expression, in terms of urban design and architecture, by disparate groupings of all members of our society (and again I am not referring to ethnic groupings), all learning from one another in time and over time, and be able to understand the total society as a learning growing system which has to be allowed into the process of making architectural meaning?

\section{REFERENCES}

Abraham, W.E. 1967 [1962]. The mind of Africa. London: Weidenfeld \& Nicolson.

Bakker, T.M. 1992. Fanon's colonial world view: Do we have tainted spectacles. Proceedings of the 10th annual congress of PASA, 30 Sept-2 Oct 1992, Stellenbosch, RSA. Pretoria: Psychological Association of South Africa.

Bateson, G. 1972. Steps to an ecology of mind. New York: Ballantine.

Bateson, G. 1985. Mind and nature. London: Fontana.

Croce, B. 1970 [1941]. History as the story of liberty. New York: Univerity Press of America.

Davidson, B. 1991. Africa in history. London: Phoenix.

Fanon, F. 1973 [1961]. The wretched of the earth. Transl, by C. Farrington. Harmondsworth: Penguin.

Fisher, R.C. 1992. An ecosytemic role for architectural style: Bearing the plan in mind. Unpublished $\mathrm{PhD}$-Thesis. University of Pretoria.

Jahoda G. 1984. Do we need a concept of culture?. Journal of Cross-Cultural Psychology, vol. 15, p.139-151.

Gebhard, W. 1992. Shades of reality: black perceptions of reality. Vol 3. African literatures in English. Essen: Die Blaue Eule.

Hountondji, P.J. 1983 [1976]. African philosophy. Myth and reality. English transl. by $\mathrm{H}$. Evans. London: Hutchinson University Library for Africa.

Kostof, S. 1985. A history of architecture. Settings and rituals. New York: Oxford University Press.

Laszlo, E. 1973. Introduction to systems philosophy. New York: Harper \& Row.

Mbiti, J.S. 1961. African religions and philosophy. London: Heinemann. 
Mowoe, I.J. \& Bjornson, R. (Eds). 1986. Africa and the West. The legacies of Empire. New York: Greenwood Press.

Mudimbe, V.Y. 1988. The invention of Africa: Gnosis, philosophy and the order of knowledge. Bloomington: Indiana University Press.

Onians, J. 1988. Bearers of meaning. Princeton: University Press. Panofsky, E. 1955. Meaning in the visual arts. Garden City, NY: Doubleday Anchor Books.

Pieterse, J.N. 1992. White on black. Images of Africa and Blacks in Western popular culture. New Haven: Yale University Press.

Porthogesi, P. et al. 1981 [1980]. The presence of the past. London: Academy.

Prigogine, I. 1979. From being to becoming. San Francisco: Freeman.
Prigogine, I. et al. 1985 [1984]. Order out of chaos. London: Flamingo.

Rohner, R. 1984. Towards a conception of culture for crosscultural psychology. Journal of Cross-Cultural Psychology, vol.15, p.111-38.

Rowe, P.G. 1987. Design thinking. Cambridge: MIT Press.

Rsen, J. 1993. Studies in Metahistory. Pretoria: HSRC.

Senghor, L.P. 1965. Prose and poetry. Transl. by J. Reed \& C. Wake. London: Oxford University Press.

Toynbee, A. 1988 [1972]. A study of history. London: Thames and Hudson.

Wickert, F.A. 1967. Readings in African Psychology. From French language sources. East Lansing: African Studies Centre, Michigan State University. 